\title{
Trade Union Channels for Influencing European Union Policies
}

I Bengt Larsson'

Professor, Department of Sociology and Work Science, University of Gothenburg, Sweden

\begin{abstract}
This paper analyzes what channels trade unions in Europe use when trying to influence European Union (EU) policies. It compares and contrasts trade unions in different industrial relations regimes with regard to the degree to which they cooperate with different actors to influence EU policies, while also touching on the importance of sector differences and organizational resources. The study is based on survey data collected in 2010-201 I from unions affiliated with the European Trade Union Confederation and from below peak unions in 14 European countries. Results of the survey show that the 'national route' is generally the most important for trade unions in influencing EU policies in the sense that this channel is, on average, used to the highest degree. In addition, the survey delineates some important differences between trade unions in different industrial relations regimes with regard to the balance between the national route and different access points in the 'Brussels route'.
\end{abstract}

\section{KEY WORDS}

Industrial relations / trade unions / cooperation / lobbying / EU policies

\section{Introduction}

ompared with other regions in the world, many trade unions in Europe have a strong national position. Transnationally, the position of trade unions is also relatively strong, since European trade unions have institutionalized arenas in which to influence European Union (EU) policies (Bieler \& Schulten, 2008; Clauwaert, 2011; Welz, 2008). European trade union cooperation is well developed and includes both sector and cross-sector activities such as exchanging information and collaborating on training programs, producing statements and mobilizing demonstrations, coordinating collective bargaining, and participating in a social dialogue with European employer organizations through the sectoral European Trade Union Federations (ETUFs) ${ }^{1}$ and the cross-sectoral European Trade Union Confederation (ETUC) (Glassner \& Pochet, 2011; Traxler et al., 2008).

While some transnational cooperation aims to improve dialogue and bargaining strategies, much of it is concentrated on EU policies, and trade unions have an important role to play in the development of the 'social market economy' introduced in the

\footnotetext{
${ }^{1}$ Bengt Larsson, Department of Sociology and Work Science, University of Gothenburg, Box 720, SE 40530 Gothenburg, Sweden. Email: bengt.larsson@socav.gu.se. The research on which this article is based was financed by the Swedish Council for Working Life and Social Research (FAS) and the Swedish Foundation for Humanities and Social Sciences (RJ)
} 
Lisbon Treaty. However, trade unions face challenges that must be overcome in order to influence the EU. They are experiencing setbacks through declining membership and a reduced scope for action not only due to rulings by the European Court of Justice (e.g., the so-called Laval Quartet) but also because of austerity policies (Bücker \& Warneck, 2010; Marginson, 2014; Scheuer, 2011). In addition, many obstacles to cross-border cooperation remain from the past such as institutional differences, scarcity of union resources, and low interest in the European level among members (Furåker \& Bengtsson, 2013; Larsson, 2012). The difficulties in trade union cooperation also increased after the EU enlargements because of differences in working conditions, wage levels, and union structure and interest between old and new member states (Meardi, 2012).

All of this makes it important to study how national trade unions in Europe approach EU policies. There is some comparative work relating to this issue, showing that trade unions not only face different challenges in different countries (GumbrellMcCormick \& Hyman, 2013) but also that their views on how to influence EU policies varies: generally speaking Anglo-Saxon and Scandinavian trade unions have a tradition of being more 'Eurosceptic' or 'defensive' than continental and southern trade unions. This has been shown, for example, through a hesitancy to give ETUC a strong mandate, and in their reluctance to the development of supra-national wage policies and regulations (e.g., Busemeyer et al., 2008; Furåker \& Lovén Seldén, 2013; Glassner \& Vandaele, 2012; Gumbrell-McCormick \& Hyman, 2013). In addition, there have been differences between more 'activist' approaches among trade unions in the southern and some continental European countries - though with a great internal variation depending on ideology - and more 'constructive' or 'partnership'-oriented trade unions in the north and in the northern continental countries (Larsson, 2014; Mitchell, 2007). However, most previous research focuses on either a few trade unions or gives a general view without specifying how trade unions balance different channels to influence EU policies. The only study presenting specific information on the latter issue is Nergaard and Dølvik (2005), though with a focus on the Nordic countries only. In addition, there is research focusing on a particular forum of influence, such as social dialogue and cooperation through the ETUC (e.g., Clauwaert, 2011; Dølvik, 1997; Gold et al., 2007; Müllensiefen, 2012), sectoral social dialogue (e.g., Kaeding \& Obholzer, 2012; Keller \& Weber, 2011; Léonard et al., 2011, 2012), coalitions with non-governmental organizations (NGOs) (e.g., Bieler \& Goudriaan, 2011), or on trade unions' influence on singular policy issues such as the services directive (e.g., Bernaciak, 2011; Dølvik \& Ødegård, 2012).

In sum, the picture given from previous research is not only very detailed but also quite fragmented. Therefore, comparative analyses that provide a more general view of differences in trade unions' use and assessment of the broad range of access points to EU policies may contribute to our further understanding of the challenges that trade unions face. The reason is that differences in strategies between trade unions make up a challenge of its own in influencing EU policies. This paper analyzes what channels national trade unions use when trying to influence EU policies, more specifically the degree to which they cooperate with different actors, organizations, or institutions in order to influence these policies. The purpose of the study is to describe what channels are seen as more and less important by trade unions and to explain differences between trade unions across Europe on these issues.

The analysis is based on the assumption that differences in national industrial relations and sectoral differences affect trade unions' strategies to influence EU policy. It 
begins with a discussion on previous research on the policy-influencing channels for trade unions, followed by a discussion on industrial relations regimes and sector differences, and their potential explanatory power on strategies of cooperation. Subsequently, the data and some methodological considerations are presented before turning to the analyses. The study is based on survey data collected in 2010-2011 from unions affiliated with the ETUC and from below peak unions in 14 European countries.

\section{Previous research on trade unions' access points to EU policies}

Although trade unions in Europe are cooperating to strengthen their position in relation to employer organizations, and at times act as a mobilizing social movement (Gajewska, 2008; cf. Larsson, 2014), their main strategy at the European level is said to be that of 'workers' lobby organizations' toward EU legislation and policies (Bieler \& Schulten, 2008, p. 239; cf. Dølvik, 1997, pp. 127ff.; 134ff.).

The multilevel structure of institutions in the EU has created a variety of access points for interest groups, in particular for trade unions, since they have been given formal status as social partners, as represented by the ETUC and ETUFs (Clauwert, 2011; Greenwood, 2007, p. 23ff.; Welz, 2008). However, the complexity of the EU institutional framework has a downside in that there is little chance of having a real impact on policies. Although EU policies and legislation affect trade unions and their members, social dialogues only focused on some policy areas such as working conditions, health and safety, and equal rights. Other areas, such as wage bargaining, the right to strike, and the right to association, are defined as being outside EU competencies of the 'social dimension' (Bieler, 2005; Greenwoood, 2007, p. 95; Smismans, 2012). With regard to lobbying EU institutions, trade unions have been said to be less influential than organized business (Dølvik \& Ødegård, 2012). For these and other reasons, trade unions are considered 'structurally disadvantaged in the EU institutional set-up' (Bieler \& Goudriaan, 2011, p. 182f.; Bieler \& Schulten, 2008, p. 24). Their influence on EU policies through dialogue is also limited by not having any veto points. Trade unions must work with the European Commission rather than against it if they are to have any influence (Schroeder \& Weinert, 2004). Thus, there is a risk for trade union organizations to be co-opted by the European Commission's agenda in a symbolic 'euro-corporatism' that legitimizes rather than influences EU policies and legislation (Bieler \& Schulten, 2008; Kaeding \& Obholzer, 2012).

Regardless of these problems, it is important to not only study trade union cooperation strategies in relation to EU policy access points but also how national trade unions in Europe weigh the importance of different channels for influencing policies. Although there is much research on the social dialogues, which are the main fora for influencing EU policies, there is less research on other avenues of influence, and there is a lack of comparative research trying to understand the importance given these different channels by the trade unions themselves.

However, on the basis of previous studies, it is possible to give a brief characteristic of some of the main channels for such influence and their importance as access points to EU policies. Conceptually, one main distinction of such EU policy influencing channels is that between those making up a 'national route' and those belonging to a 'Brussels route' (Greenwood, 2007, p. 25ff., p. 105ff.). Since the focus of this paper is on national trade 
unions, this overview will focus mainly on the Brussels route, since the national route consists of cooperation with or lobbying toward political institutions and actors at the national level. The national route, and the unions standing nationally, will be discussed briefly in the subsequent section. The empirical analysis will also focus on both routes, while disentangling differences between the various channels of the Brussels route. As will be shown, there is an important difference between trade unions emphasizing the work through their own channels to Brussels and unions that place greater focus on working through collaborative efforts with unions from other countries.

\section{Trade union channels for influencing EU policies}

Although the number of lobby actors has increased during the last decades, trade union organizations have a particular access to EU policies and their 'social dimension' through social dialogue (Waddington, 2005). The ETUC, created in 1973, aimed to both lobby the European Commission and obtain access to its decision-making structures. With the institutionalization of social dialogue in 1987, the ETUC acquired a means of forming binding agreements with European employer organizations, which were to be converted into directives. The social partners thus obtained a function as a corporatist, semi-legislative organ (Welz, 2008, p. 244ff.). A second avenue of social dialogue that already existed from 1991, but that was first being practiced in 1997, was that of giving unions and employer organizations the right to negotiate 'autonomous agreements', which were to be implemented by the organizations rather than through directives (Gold et al., 2007; Welz, 2008, p. 258ff; 339ff.).

The results from both of these avenues of social dialogue are considered to be rather modest in terms of their effects on European workers (Clauwaert, 2011; Glassner \& Pochet, 2011; cf. Keller \& Weber, 2011; Léonard et al., 2011). In addition, the diminishing pressure from the European Commission on the parties to negotiate since the late 1990s has led to a decrease in agreements reached (de Boer et al., 2005). However, trade union collaboration through the ETUC and social dialogue is still one of the main channels for EU policy influence, which, for instance, was shown in connection to struggles over the services directive (Bieler \& Schulten, 2008; Dølvik \& Ødegård, 2012).

The European Parliament (EP) and its members and groups also interest trade unions with regard to cooperation, since it has the power to amend and co-decide legislation. One organized avenue to pursue influence is the monthly meeting between the ETUC and the trade union intergroup of the EP, which consists of 'union-friendly' EP members from diverse political groups (Bieler, 2005; Erne, 2008, p. 38; cf. Dølvik \& Ødegård, 2012). Moreover, trade unions have links to the Party of European Socialists, which is also an access point to the EP (Greenwood, 2007, p. 37f., p. 104).

The social dialogue never included macro-economic issues, but trade unions have also been given access points through consultation with, for example, the Economic and Social Committee, the Standing Committee on Employment, and the Macroeconomic Dialogue related to the European Employment Strategy (EES). In all of these, however, trade unions have limited power, since these are basically channels for information and advice rather than influence (Greenwood, 2007, p. 40, 104; Schroeder \& Weinert, 2004; Welz, 2008, p. 217ff., p. 246ff., p. 278f.). Because of the focus on targets, guidelines, national action plans, indicators, benchmarks, and evaluations through the Open 
Method of Coordination (OMC), the EES has furthermore been described as a 'managerial social dialogue' in which social partners are invited only at a late stage, and only in a reactive role. Furthermore, the OMC pushed back the possibility for trade union influence to the national level because of the importance put on national action plans and social pacts (Gold et al., 2007; cf. Müllensiefen, 2012).

As the expectations on cross-sectoral social dialogue decreased in the late 1990s, the importance of sectoral social dialogue increased, not least with the establishment of Sectoral Social Dialogue Committees in 1998 (Keller \& Weber, 2011). These committees are coordinated on the trade union side by the ETUFs and are seen as forums for consultation on European policies by the European Commission. Although the outcome of the dialogues varies between sectors, joint statements and recommendations are the main result (de Boer et al., 2005; Keller \& Weber, 2011; Léonard et al., 2011). Only a few binding framework agreements have been negotiated. In addition, trade unions have mainly had a consultation role, since the majority of the agreements are statements relating to activities and policies put forth by the European Commission. All in all, the national effect of these agreements is consequently quite modest, not least because it is at the national level that the forms of implementation are decided. This has further pushed back the possibility of influence to the national level, as discussed above (Gold et al., 2007). Still, the sector dialogue is an important forum in influencing European policies (Léonard et al., 2011: 257; cf. de Boer et al., 2005; Keller \& Weber, 2011). There are also examples of ETUFs cooperating with other social movements and NGOs (Bieler \& Goudriaan, 2011; Bieler \& Schulten, 2008; Waddington, 2005). Such cooperation may be of some importance in influencing EU policies, though in more indirect ways, and it is not always that easy to accomplish, since there is often a bit of reluctance from both sides (Bieler \& Lindberg, 2011; cf. Gumbrell-McCormick \& Hyman, 2013, p. 145ff.).

Besides the ETUC and ETUFs, there are also a number of regionally based transnational networks, including the Doorn group and the Inter-Regional Trade Union Councils, through which trade unions cooperate, mainly to coordinate national rather than EU-level strategies. However, others, such as the Council of Nordic Trade Unions (NFS) and the Baltic Sea Trade Union Network, are also used for coordination strategies toward EU policies. One further avenue to influence EU policies consist of national trade unions' own offices in Brussels, many of which were established during the 1990s, and that work to strengthen their own national channels to EU institutions (Svensson \& Jacobsson, 2009).

\section{Industrial relations regimes and sector differences}

National trade unions' strategies are not only influenced by the formal characteristics of the channels discussed above, also of importance are what identities and resources, and what relations to employer organizations and the state, a trade union has. These are factors that not only vary between individual unions but also across Europe and across sectors within countries (Bechter et al., 2011; Gumbrell-McCormick \& Hyman, 2013; Visser et al., 2009). Differences in national industrial relations, defined as 'institutional arrangements shaped by legislative frameworks, historical traditions, accumulated vested interests and learned patterns of behavior' (Hyman, 1994, p. 1) may be expected to have an effect on both the general degree of engagement in European trade union 
cooperation and the more specific balance between what channels to work through. There are at least two reasons for this.

Firstly, trade unions pursue their interest within different contextual settings and face different challenges (Gumbrell-McCormick \& Hyman, 2013). National trade unions' standpoints and interests may influence what relation they have to joint cooperative strategies, since they view things differently on gains and concessions in coordinating joint policy activities with other trade unions. This may affect not only what issues they are focused on but also their choice of working cooperatively through European cooperative fora such as the ETUC and ETUFs, versus trying to pursue them through their own national or Brussels channels (cf. Busemeyer et al., 2008).

Secondly, choice of strategy depends not only on the importance of specific EU policies or issues for national unions, but it may also depend on differences in resources and traditions of social partnership, corporatism, and conflict, and to what degree trade unions enjoy access to decision-making at the national level. One could suspect that trade unions with a strong national standing might emphasize the importance of working through the national route, whereas those with a weak position may put more weight on collaborating with more resourceful unions such as through the ETUC and ETUFs. In addition, however, unions with a strong national standing may also have greater organizational resources, enabling them to also work through their offices in Brussels. They may also be better equipped to partake in the collaborative efforts through the ETUC and ETUFs (cf. Léonard et al., 2012; Princen \& Kerremans, 2012).

In order to analyze the effects of such differences on the degrees of cooperation and choice of channels to pursue influence on EU policies, I will use a simplified theoretical model based on the categorization of national industrial relations into a smaller set of regimes or models of industrial relations, which cluster countries on the basis of similarities (Bieler \& Schulten, 2008, p. 235f.; Gumbrell-McCormick \& Hyman, 2013, p. 8-28; Meardi, 2012; Vos, 2007). Most of these typologies distinguish between five different models or regimes, which here will be denominated according to the most elaborate attempt at categorization (Visser et al., 2009, p. 49f.). Since there is not enough space to elaborate the internal variation or even all the characteristics of these different regimes, only a brief overview of some main characteristics is given in Tab. 1 .

These industrial relations regimes are not internally homogeneous. There is not only a lot of variation within these regimes that cannot be accounted for here (e.g., Glassner, 2013; Gumbrell-McCormick \& Hyman, 2013, p. 8-28; Bechter \& Brandl, 2014). As shown by Bechter et al. (2011), there is also more diversity in industrial relations across sectors within a country than within sectors in the EU 27, which makes it possible to speak of sectoral regimes of industrial relations (cf. Erne, 2008). The basis for such a perspective is that different industries are characterized by different production processes and work organizations. When you take into consideration that trade unions in different sectors also have diverging identities, resources, and relations to employers, such differences may be expected to have an effect on both the general degree of engagement in European trade union cooperation and the more specific balance between what channels to work through. The main arguments for that are below.

Some industries, particularly in manufacturing, are highly exposed to international competition, since their product markets are highly integrated and their work organization enables a high degree of production location transferability. Together with industries that have undergone liberalization such as civil aviation and telecommunications, 
Table I Industrial relations regimes in Europe

\begin{tabular}{|c|c|c|c|c|c|}
\hline & $\begin{array}{l}\text { Social } \\
\text { partnership } \\
\text { (Cont.) }\end{array}$ & $\begin{array}{l}\text { Polarized/ } \\
\text { state-centered } \\
\text { (South) }\end{array}$ & $\begin{array}{l}\text { Organized } \\
\text { corporatism } \\
\text { (North) }\end{array}$ & $\begin{array}{l}\text { Liberal } \\
\text { pluralism } \\
\text { (Angl.) }\end{array}$ & $\begin{array}{l}\text { Fragmented/ } \\
\text { state-centered } \\
\text { (East) }\end{array}$ \\
\hline $\begin{array}{l}\text { Union } \\
\text { density }\end{array}$ & Moderate & Low & High & Moderate & Low \\
\hline $\begin{array}{l}\text { Social partner } \\
\text { organization }\end{array}$ & $\begin{array}{l}\text { Both sides } \\
\text { strong }\end{array}$ & $\begin{array}{l}\text { Variable (TU } \\
\text { strength through } \\
\text { action) }\end{array}$ & $\begin{array}{l}\text { Both sides } \\
\text { strong }\end{array}$ & Both sides strong & $\begin{array}{l}\text { Both sides } \\
\text { weak }\end{array}$ \\
\hline $\begin{array}{l}\text { Power } \\
\text { balance }\end{array}$ & Balanced & Alternating & Labor-oriented & Employer-oriented & $\begin{array}{l}\text { Employer- } \\
\text { oriented }\end{array}$ \\
\hline $\begin{array}{l}\text { Bargaining } \\
\text { style }\end{array}$ & $\begin{array}{l}\text { Integrated/ } \\
\text { coordinated }\end{array}$ & $\begin{array}{l}\text { Conflict-oriented, } \\
\text { uncoordinated }\end{array}$ & $\begin{array}{l}\text { Integrated/ } \\
\text { coordinated }\end{array}$ & $\begin{array}{l}\text { Conflict- } \\
\text { oriented/ } \\
\text { uncoordinated }\end{array}$ & $\begin{array}{l}\text { Acquiescent/ } \\
\text { uncoordinated }\end{array}$ \\
\hline $\begin{array}{l}\text { State role } \\
\text { in } I R\end{array}$ & $\begin{array}{l}\text { Shadow of } \\
\text { hierarchy }\end{array}$ & $\begin{array}{l}\text { Frequent } \\
\text { intervention }\end{array}$ & $\begin{array}{l}\text { Limited/ } \\
\text { mediating }\end{array}$ & Non-intervention & $\begin{array}{l}\text { Limited/ } \\
\text { Transition- } \\
\text { oriented }\end{array}$ \\
\hline $\begin{array}{l}\text { Partners' role } \\
\text { in public policy }\end{array}$ & $\begin{array}{l}\text { Institutional- } \\
\text { ized } \\
\text { influence }\end{array}$ & $\begin{array}{l}\text { Irregular| } \\
\text { politicized }\end{array}$ & $\begin{array}{l}\text { Institutionalized } \\
\text { influence }\end{array}$ & Rare/event-driven & $\begin{array}{l}\text { Irregular| } \\
\text { politicized }\end{array}$ \\
\hline
\end{tabular}

Sources:Visser et al., 2009; cf. Bechter \& Brandl, 20।4; Gumbrell-McCormick \& Hyman, 2013.

and construction because of the Posting of Workers Directive, they have had the greatest cause to collaborate across borders to influence EU policies, since they are directly affected by them (Glassner \& Pochet, 2011; Müller et al., 2010; Pulignano, 2009). As noted by Bieler (2005), one can also assume that trade unions in sectors that are under transnational competitive pressure are more likely to be active in transnationally oriented cooperation and lobbying than those still oriented toward national markets (cf. Gumbrell-McCormick \& Hyman, 2013, p. 160).

The more sheltered industries, such as public services like education and healthcare and private services like hairdressing, are less exposed not only to international competition in their consumer markets but also to production location transferability (Bechter et al., 2011; Glassner \& Pochet, 2011, p. 13). They have been under less external pressure to engage in cross-border cooperation and have developed transnational trade union cooperation and sector dialogue later and in a weaker form (European Commission, 2010; cf. Furåker \& Bengtsson, 2013; Larsson, 2012, 2014).

In addition, there are sectoral differences in union organizations and resources. One such difference is that trade unions in manufacturing traditionally have a strong organization and resources nationally in comparison to unions in the services sector and those organizing professions (e.g., Bieler \& Lindberg, 2011, p. 223). The metal industry may be the ideal case for this, and it is here that one finds the most far-reaching transnational coordination of activities between unions (Glassner \& Pochet, 2011; Müller et al., 2010; Pulignano, 2009). Against this background, it seems important to also take sectoral differences into account when studying differences in how national trade unions in Europe approach EU policies. 


\section{Data and methods}

The study is based on survey data collected in 2010-2011 from trade unions affiliated with the ETUC and from below peak unions in 14 European countries (see Tab. 2). The 512 organizations targeted had approximately 10,000 or more members in order to exclude minor trade unions. The overall response rate was $49 \%(n=250)$, though it was higher in most countries $76 \%$ overall, if excluding Poland and France, for which there was difficulty in reducing the number of responding organizations and also low response rates). In order to produce good validity, respondents at central positions in the organizations were selected. As a result, just over half of the returned questionnaires were filled out by the secretary-general, the president, or the vice-president, and one-quarter were filled out by an international secretary/correspondent. The nine responses from the ETUFs, which are also members of the ETUC, were excluded in the below analyses because of the focus on national trade unions. This resulted in a total of 241 cases.

The analyses are presented in the form of cross-tables with whole data set percentages and means; multiple regressions using a summated index of all items in order to explain the overall degree of cooperation; an analysis of compared means with analysis of variance (ANOVA) statistics to show industrial relations regime differences on the

Table II Sample and response rates

\begin{tabular}{lccc}
\hline Country & Sample (freq.) & Response rate \% (freq.) & Percentage of all responses \\
\hline Austria & 8 & $88(7)$ & 2.8 \\
\hline Belgium & 28 & $39(11)$ & 4.4 \\
\hline Denmark & 29 & $69(20)$ & 8 \\
\hline Finland & 38 & $42(16)$ & 6.4 \\
\hline France & 101 & $18(18)$ & 7.2 \\
\hline Germany & 27 & $59(16)$ & 6.4 \\
\hline Great Britain & 31 & $61(19)$ & 7.6 \\
\hline Iceland & 6 & $50(3)$ & 1.2 \\
\hline Ireland & 15 & $33(5)$ & 2 \\
\hline Norway & 34 & $71(24)$ & 9.6 \\
\hline Poland & 131 & $15(20)$ & 5.6 \\
\hline Spain & 26 & $54(14)$ & 15.6 \\
\hline Sweden & 39 & $100(39)$ & 3.2 \\
\hline Switzerland & 23 & $35(8)$ & 8.4 \\
\hline Other country* & 48 & $33(16)$ & 3,6 \\
\hline ETUFs & 12 & $75(9)$ & 100 \\
\hline Total & $(512)$ & $49(250)$ &
\end{tabular}

*Peak level federations from other European countries that are ETUC members. Besides the 12 ETUFs and the associated organization EUROCADRES and four national observer organizations, the ETUC had at this point in time 82 national member organizations. Since 34 of the member organizations were in the 14 countries above, 48 national peak level organizations were included in this category of 'other'. 
individual items; and finally an index showing the difference between the use of 'own' versus 'cooperative' channels.

The dependent variables in the analyses are based on seven items relating to a joint question: To what degree does your organization cooperate with the following actors in order to influence EU policies? The following seven actors/channels discussed in previous research section were listed: 1) ETUC; 2) ETUFs; 3) Trade union offices in Brussels; 4) National authorities or political parties; 5) Cross-national/regional union networks (e.g., IRTUCs, Doorn, NFS); 6) other NGOs or networks (e.g., European Women's Lobby, AGE, European Anti-poverty network); and 7) members or political groups in the European Parliament. For all these items, the respondents could choose between the alternatives 'To a high degree', 'To some degree', 'To a low degree', 'Not at all', or 'Do not know'. The last category was subsequently recoded as missing, so that the analyses only include graded statements.

The independent variables in the analyses were constructed in the following way: the above classification of industrial relations regime in Europe was used as the focal independent variable (cf. Visser et al., 2009). The organized corporatism (Nordic) regime $(\mathrm{n}=102)$ consists of respondent organizations from Denmark (20), Finland (16), Iceland (3), Norway (24), and Sweden (39). The social partnership (CWECs) regime ( $\mathrm{n}=46$ ) consists of Austria (7), Belgium (11), Germany (16), Lichtenstein (1), Luxembourg (1), the Netherlands (1), Slovenia (1), and Switzerland (8). The polar$\mathrm{ized} / \mathrm{state}-\mathrm{centered}$ (SEECs) regime $(\mathrm{n}=35)$ consists of France (18), Italy (2), Portugal (1), and Spain (14). The liberal pluralism (WECs) regime $(n=27)$ consists of Cyprus (3), Ireland (5), and the UK (19). Finally, the fragmented/state-centered (EECs) regime $(\mathrm{n}=31)$ consists of Bulgaria (2), Croatia (1), Estonia (1), Hungary (3), Latvia (1), Lithuania (1), Poland (20), Romania (1), and the Slovak Republic (1). An important factor to control for when comparing these regimes is that they include trade unions from countries that are not members of the EU (i.e., Croatia, Iceland, Lichtenstein, Norway, and Switzerland). Although trade unions from these countries are members of the ETUC, ETUFs, and other trade union networks, and are affected by EU policies through the EEA or individual agreements, this may affect their degree of cooperation in order to influence EU policies, since they have less connection to some of the EU policy access points.

With regard to the sector classifications, one would ideally use a theoretically stringent sector division (e.g., Crouch, 1999). However, since unions organize according to different principles across Europe, it was difficult to perform such clear-cut classifications. Therefore, I have combined the classification of economic activities in NACE with the occupational classifications of ISCO-88 (COM). The analyses are based on seven categories: professions $(n=63)$ comprise unions that mainly organize occupations at levels 1 or 2 in ISCO-88 (COM) such as lawyers, engineers, doctors and nurses, dentists, psychologists, teachers, and social workers; services (57) comprise unions that organize service occupations at lower levels of ISCO-88; manufacturing (40) comprises not only unions that organize in manufacturing but also industries organizing in chemicals, mining, and forestry, albeit with their main interest in the manufacturing industries; construction (14) is separated from the other sectors, since it has been under increasing competitive pressure due to the increase of posted workers following the inclusion of new EU member states in 2004 and 2007; transportation (11) is separated from services in general, since it generally has a higher degree of internationalization than 
the services industries in general; peak-level confederations (44) comprise the national member organizations of the ETUC; and cross-sector unions (12) comprise those unions that could not be classified, since they organize in more than one of the above sectors.

The main analytic indicator of the resources of individual trade unions is the size of the organization in terms of membership numbers. Although this is a crude indicator of resources, it seems reasonable because the number of members affects not only the financial situation of a trade union but also its negotiating power and interest from other actors in cooperating or negotiating with them. Since official figures of membership numbers were not possible to obtain, the size analyses are based on six predefined classes included in the questionnaire.

There are some obvious limitations to the data set. Firstly, there is an overrepresentativeness of trade unions from the Nordic countries, both because of an overselection in the sample and the high response rates. Secondly, two of the regimes, the polarized/state-centered (SEECs) and the fragmented/state-centered (EECs), are represented mainly by their ETUC member organizations in addition to a number of below peak level unions in just one or two countries within that regime. As a consequence, the representativeness of the data set for these regimes is not as good as for the other regimes. In addition, the sector classification is crude and gives no possibility to account for internal variation within the sectors, for example, between nationally bound service industries such as personal services and more internationalized industries such as banking.

These biases must be taken into account when interpreting the results. To some degree, they have been reduced in the regressions by controlling for sector, size of the organization, and EU membership in the analyses of the focal relationship between industrial relations regimes and the degree to which they cooperate in order to influence EU policies. In addition, with regard to the dependent variable, the data provide crude measures of how trade unions cooperate to influence EU policies, since the question is stated in a general way, whereas actual attempts to influence EU policies likely differ depending on specific issues. Even so, one may assume that the results give an overall indication of differences in the ways trade unions cooperate. To my knowledge, and despite these limitations, this data set is still the best comparative data available today on how trade unions in Europe assess and prioritize between different channels to influence EU policies. Thereby, these results contribute by giving an overall depiction of something that has mainly been covered by qualitative case studies and studies of singular channels/fora previously. In addition, the article contributes by trying to test theoretical explanations more systematically than in previous research.

\section{Results}

Trade unions in Europe generally agree on the importance of cooperating transnationally and engaging in European issues (Furåker \& Bengtsson, 2013). Moreover, most of them see the need to adjust their aims and methods to the actual decision-making process at the EU level (Larsson, 2014). As can be seen from the means in Tab. 3, national authorities or political parties are, generally speaking, the most used channels for 
Table III Channels for influencing EU policies

\begin{tabular}{lcccccc}
\hline $\begin{array}{l}\text { To what degree does your organi- } \\
\text { zation cooperate with the follow- } \\
\text { ing actors in order to influence EU } \\
\text { policies? }\end{array}$ & $\begin{array}{l}\text { MEAN } \\
(\mathbf{I}-\mathbf{4})^{* *}\end{array}$ & $\begin{array}{c}\text { To } \\
\text { a high } \\
\text { degree }\end{array}$ & $\begin{array}{c}\text { To } \\
\text { some } \\
\text { degree }\end{array}$ & $\begin{array}{c}\text { To } \\
\text { a low } \\
\text { degree }\end{array}$ & $\begin{array}{c}\text { Not } \\
\text { at } \\
\text { all }\end{array}$ & $\mathbf{n}^{*}$ \\
\hline National authorities or political parties & 3.02 & 32 & 43 & 19 & 5 & 228 \\
\hline ETUFs & 2.81 & 38 & 27 & 12 & 23 & 212 \\
\hline Trade union offices in Brussels & 2.67 & 26 & 34 & 22 & 19 & 209 \\
\hline ETUC & 2.59 & 22 & 35 & 25 & 18 & 224 \\
\hline Cross-national/regional union networks & 2.51 & 22 & 31 & 22 & 24 & 212 \\
\hline Members or political groups in the EP & 2.43 & 15 & 35 & 27 & 22 & 227 \\
\hline Other NGOs or networks & 2.09 & 8 & 26 & 33 & 33 & 219 \\
\hline
\end{tabular}

Percentages and means $(n=24 I)$.

*'Do not know' is recoded as missing. Percentages are rounded off. *** 'Not at all' $=1$, 'To a high degree' $=4$.

national trade unions to influence EU policies. In that sense, the national route is given more importance than any of the channels in the Brussels route when viewed separately, followed by the institutionalized trade union channels at the European level: the ETUFs, trade unions' own offices in Brussels, ETUC, and cross-national or regional trade union networks. At the bottom end of the table are members or political groups in the EP, and, finally, with considerably lower mean, cooperation with other NGOs or networks.

These results can be compared with a study of trade unions in the Nordic countries performed by Nergaard and Dølvik (2005). Their results are similar in terms of the ranking of importance of different channels. The Nordic trade unions saw their own peak-level confederations and national authorities as the most important channels for influencing EU decision-making, followed by the ETUFs, ETUC, and their own offices in Brussels. Of least importance was the regional Council of Nordic Trade Unions, NFS (Nergaard \& Dølvik, 2005, p. 92-94). Although such a comparison is problematic because of the differences in scope of the surveys, the similarities in the results are striking and suggest that there is some stability in the overall importance of different EU policy-influencing channels for national trade unions. Yet, there is also much variation, as can be seen in Tab. 3. For example, almost $25 \%$ of the unions state that they have little or no cooperation with national authorities or political parties, though this generally is the most commonly used channel.

\section{Differences in overall degrees of cooperation}

One way of assessing the importance of industrial relations regimes is to analyze the effect they have on the overall degree of cooperation to influence EU policies. In order to do that, I have constructed a summated index of all the seven items in Tab. 3. ${ }^{2}$ The results of the regressions using this index are presented in Tab. 4. The first model shows 
Table IV Cooperation in order to influence the EU (summated index)

\begin{tabular}{lllll}
\hline & Model I & Model 2 & Model 3 & Model 4 \\
\hline Industrial relations regime & & & & \\
\hline Social partnership (Cont.) (ref) & & & & \\
Polarized/state-centered (South) & -1.60 & $-2.41 *$ & -1.65 & -0.45 \\
Organized corporatism (North) & $-2.83 * *$ & $-2.55 * *$ & $-1.59+$ & -1.08 \\
Liberal pluralism (Angl.) & $-4.47 * *$ & $-5.27 * * *$ & $-4.37 * * *$ & $-3.42 * *$ \\
Fragmented/state-centered (East) & $-5.17 * * * * 17$ & $-5.85 * * *$ & $-7.16 * * *$ & $-4.39 * * *$ \\
\hline
\end{tabular}

\section{EU membership}

\begin{tabular}{|c|c|c|c|c|}
\hline \multicolumn{5}{|l|}{ Member state (ref) } \\
\hline Non-member state & & $-4.12 * * * *$ & $-4.48 * * *$ & $-3.40 * * * *$ \\
\hline \multicolumn{5}{|l|}{ Sector } \\
\hline \multicolumn{5}{|l|}{ Peak level (ref) } \\
\hline Cross-sector & & & -2.25 & -1.20 \\
\hline Manufacturing & & & $-4.33 * * * *$ & $-2.05 *$ \\
\hline Construction & & & -6.21 ***** & $-3.32 *$ \\
\hline Services & & & $-5.74 * * *$ & $-3.31 * * * *$ \\
\hline Professions & & & $-7.09 * * * *$ & $-4.04 * * * *$ \\
\hline Transportation & & & $-6.83 * * * *$ & $-4.52 * *$ \\
\hline \multicolumn{5}{|c|}{ Number of members (TU size) } \\
\hline \multicolumn{5}{|c|}{$>500,000$ (ref) } \\
\hline $100,000-499,999$ & & & & $-1.83+$ \\
\hline $50,000-99,999$ & & & & $-3.87 * * *$ \\
\hline $20,000-49,999$ & & & & $-3.23 * *$ \\
\hline $10,000-19,999$ & & & & $-6.12 * * * *$ \\
\hline$<10,000$ & & & & $-7.51 * * * * *$ \\
\hline Intercept & $20.44 * * * *$ & $21.25 * * *$ & 25.57 **** & $25.84 * * * *$ \\
\hline $\mathrm{R}^{2}$ adj. & 0.091 & 0.17 & 0.40 & 0.54 \\
\hline$n$ & 173 & 173 & 173 & 173 \\
\hline
\end{tabular}

the effect of industrial relations regimes on the overall degree of cooperation, and the second to fourth when controlling for EU membership, sector variation, and organization size. As can be seen from the adjusted $\mathrm{R}^{2}$, the first model explains less than $10 \%$ of the variation, so the importance of industrial relations regimes may not seem that great. However, this figure increases to $17 \%$ when introducing EU membership in model 2, and there are in fact significant effects of industrial relations regimes in all four models. When compared with the reference category of trade unions in the social partnership regime, there are lower degrees of cooperation among the trade unions in the liberal pluralism regime, and even less cooperation in the fragmented/state-centered regime. There is a similar if weaker tendency for trade unions in the organized corporatism regime, though it is not significant when controlling for size in model 4. 
Model 3 may also be discussed in relation to the theory of sectoral regimes (Bechter et al., 2011). The results indicate that all sectors cooperate to a lesser degree to influence EU policies than do the national, peak level unions, as well as other cross-sector unions. In addition, we find more cooperation among the unions in manufacturing than the service sectors (including transportation and construction) and trade unions organizing professionals. These effects are significant when controlling for industrial relations regimes, EU membership, and organizational size.

Finally, Models 2-4 show that EU membership and trade union size have strong and significant effects on the overall degree of EU policy influencing cooperation. To some extent, however, union size corresponds with the industrial relations regime and sector variables in that the number of members tends to be higher in some regimes and sectors than in others. Separate analyses of the data (not shown) confirm that, as compared with other regimes, there is a high percentage of large trade unions in the social partnership regime, whereas there is a high percentage of small trade unions in the fragmented/statecentered regime. In addition, there is a high percentage of large organizations among the national, peak-level unions, and cross-sector unions, as compared with sector trade unions. As a result, the reduced explanatory value of regimes and sectors when introducing organization size in the model is partly due to something that in itself is related to industrial relations regimes and sectors. In that sense, one might say that the difference between the social partnership and the other regimes, and, in particular, the fragmented/ state-centered regime, is undervalued in Model 4, as is the difference between peak-level/ cross-sector trade unions and sector trade unions.

\section{Differences in choice of channels}

Once these overall tendencies in degrees of cooperation to influence EU policy are exposed, it is possible to analyze industrial relations regime differences in more detail vis-à-vis the seven EU policy influencing channels. Table 5 compares the means for the five regimes on all seven Tab. 1 items, not just to compare the regimes but to show differences between the regimes internally with regard to the balance between different channels used. However, in this analysis, there is no control for the effect of other variables, so the interpretation must be cautious.

As summarized in Tab. 5, the tendency for trade unions in the social partnership regime to cooperate to an overall higher degree than others is related to their strong cooperation through all seven channels. In addition, one can note that the ranking of channels in this regime is quite close to the rank order of the total means. In that sense, one might think of the social partnership regime as a kind of benchmark for the comparison with other regimes, which all deviate more from the total rank order.

Trade unions in the polarized/state-centered regime have a relatively high degree of cooperation with the ETUFs and ETUC as compared with other channels, and with other regimes. In addition, they show a relatively low degree of cooperation with members or political groups in the EP.

Trade unions in the organized corporatism regime have a relatively high degree of cooperation with national authorities and political parties - somewhat lower than trade unions in the social partnership regime, but higher than in the other regimes and 
Table V Regime comparison: channels for influencing EU policies

\begin{tabular}{|c|c|c|c|c|c|c|c|}
\hline & $\begin{array}{l}\text { Total } \\
(1-4)\end{array}$ & $\begin{array}{l}\text { Social } \\
\text { partner- } \\
\text { ship } \\
\text { (Cont.) }\end{array}$ & $\begin{array}{l}\text { Polarized/ } \\
\text { state- } \\
\text { centered } \\
\text { (South) }\end{array}$ & $\begin{array}{l}\text { Organized } \\
\text { corporat- } \\
\text { ism } \\
\text { (North) }\end{array}$ & $\begin{array}{c}\text { Liberal } \\
\text { pluralism } \\
\text { (Angl.) }\end{array}$ & $\begin{array}{c}\text { Fragmented/ } \\
\text { state- } \\
\text { centered } \\
\text { (East) }\end{array}$ & $\begin{array}{c}\text { F } \\
\text { ANOVA }\end{array}$ \\
\hline $\begin{array}{l}\text { National } \\
\text { authorities } \\
\text { or political } \\
\text { parties }\end{array}$ & 3.02 & 3.21 & 2.97 & 3.14 & 2.72 & 2.67 & $3.256 *$ \\
\hline ETUFs & 2.81 & 3.10 & 3.31 & 2.61 & 2.67 & 2.54 & 3.293* \\
\hline $\begin{array}{l}\text { Trade union } \\
\text { offices } \\
\text { in Brussels }\end{array}$ & 2.67 & 3.08 & 2.68 & 2,75 & 2.22 & 2.08 & 4.938*** \\
\hline ETUC & 2.59 & 2.83 & 3.06 & 2.40 & 2.33 & 2.58 & $3.73 * * *$ \\
\hline $\begin{array}{l}\text { Cross-national/ } \\
\text { regional union } \\
\text { networks }\end{array}$ & 2.51 & 2.93 & 2.55 & 2.64 & 1.74 & 1.88 & 7.110 *⿻丷木**十 \\
\hline $\begin{array}{l}\text { Members or } \\
\text { pol. groups } \\
\text { in the EP }\end{array}$ & 2.43 & 2.65 & 2.29 & 2.40 & 2.63 & 2.17 & 1.456 \\
\hline $\begin{array}{l}\text { Other NGOs/ } \\
\text { networks }\end{array}$ & 2.09 & 2.55 & 2.13 & 1.95 & 2.17 & 1.76 & 4.158** \\
\hline $\mathrm{n}^{+}$ & $209-228$ & $40-43$ & $25-33$ & $90-99$ & $19-24$ & $25-30$ & \\
\hline
\end{tabular}

Means/ANOVA $(n=241)$.

*p $<0.05$; *** $<<0.0$ I; **** $p<0.00$ l.

+The variation in ns is related to both internal missing and that 'Do not know' was recoded to 'missing'.

relatively high as compared with other channels in their own regime. In addition, they have high degrees of cooperation through trade union offices in Brussels and through cross-national/regional trade union networks - once again not in comparison to the social partnership regime but as compared with the other regimes.

Trade unions in the liberal pluralism regime have relatively high degrees of cooperation with members or political groups in the EP and with NGOs, both in comparison to most other regimes and to other channels. Although national political parties and authorities are just as important (or more important in comparison to the degree of cooperation with NGOs), there seems to be less difference between these channels in the liberal pluralism regime than in the others. Furthermore, trade unions in this regime have low degrees of cooperation through cross-national or regional networks and trade union offices in Brussels as compared with the other regimes, with the exception of the fragmented/state-centered regime.

Trade unions in the fragmented/state-centered regime cooperate to a lower degree through all channels than all other regimes, with two exceptions. They cooperate to a slightly higher degree with cross-national or regional networks than unions in the liberal pluralism regime, but, more significantly, they give higher priority to cooperation with the ETUC than do unions in both the liberal pluralism and organized corporatism regimes.

Figure 1 highlights the differences between trade unions in the polarized state/centered regime in the south and the unions in the organized corporatism regime in the 
Figure I: Regime comparison. Own channels versus cooperative channels (Index).

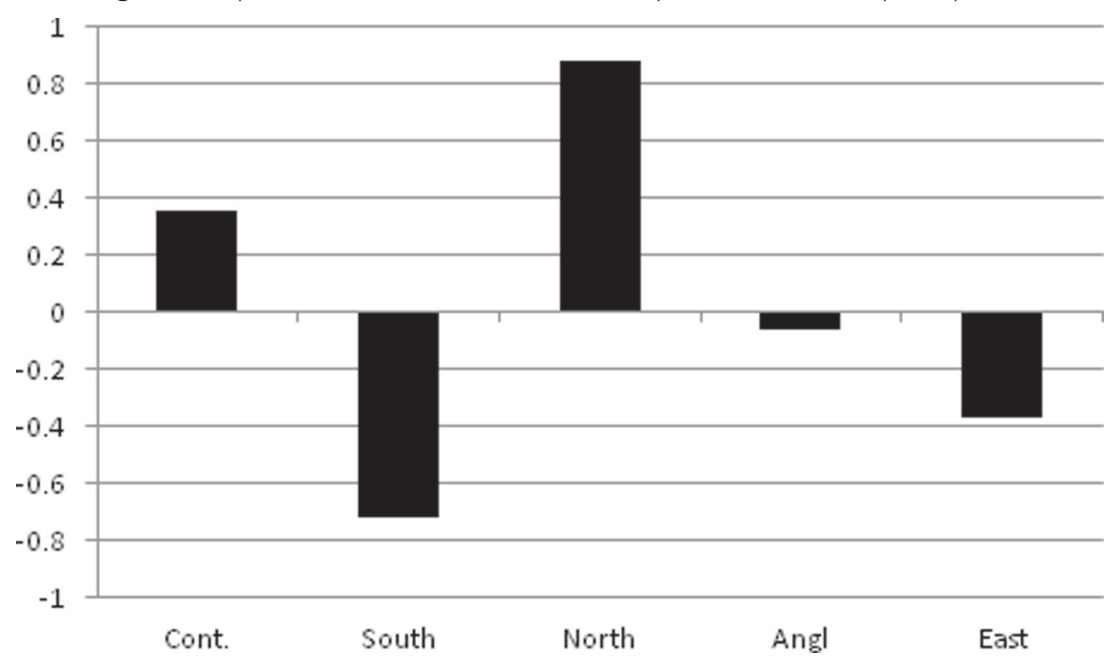

The index has a range from -8 to 8 and is based on the means for each regime in Tab. 3. The simple formula on which the index is based is index value $=(r 1+r 3)-(r 2+r 4)$, where $r=$ row in Tab. 3 .

north. It does this by presenting an index that shows the degree to which trade unions in the five regimes emphasize the importance of their own channels versus cooperative trade union channels. Their own channels are defined here as the national route as well as their own Brussels offices, whereas the cooperative channels are defined as working through the ETUFs and ETUC.

As Fig. 1 shows, the greatest difference is between the unions in the north and south. The former emphasizes the importance of working through national authorities or political parties and their own offices in Brussels, whereas the latter places greater emphasis on the collaborative work through the ETUFs and ETUC. Figure 1 also shows that the continental trade unions in the CWECs tend to give somewhat more importance to their own channels than to cooperative channels, whereas the eastern unions in the CEECs tend to emphasize the cooperative channels over their own channels. All in all, this seems to confirm the above suggestions that the differences in the national standing of trade unions in different regimes not only affect the overall level of activities but also the choice of strategy to influence the EU.

\section{Conclusion}

The first conclusion with regard to what channels national trade unions use in trying to influence EU policies concerns both the general distinction between a national route and a Brussels route, as well as the choice between different channels in the Brussels route (cf. Greenwood, 2007, p. 25ff.). While the national route is the most important in that it is on average used to the highest degree in Europe, this does not hold for all unions or in all countries. All institutionalized trade union channels that comprise important parts 
of the Brussels route followed lower degrees of cooperation: the ETUFs, trade union offices in Brussels, ETUC, and cross-national or regional networks. Direct cooperation with members or political groups in the EP followed a lower degree than the institutionalized trade union organizations. At the bottom end of the rank order was cooperation with other NGOs or networks, a fact that is not entirely surprising given the somewhat expectant or skeptical approach toward NGOs that exist among trade unions in many countries on issues other than international development (Gumbrell-McCormick \& Hyman, 2013, p. 145ff.; cf. Bieler \& Lindberg, 2011).

This simple picture gets more complicated when looking at differences between different regimes and sectors, and when controlling for EU membership and size of trade unions. EU membership and organization size matter in the sense that trade unions in EU member countries and larger unions tend to cooperate to a higher degree in trying to influence EU policies than unions in non-EU member countries and smaller unions. The effect of size may be explained in that resources are needed to pursue such cooperation, which has also been shown to be of importance for other forms of cooperation between trade unions in Europe (Furåker \& Bengtsson, 2013; Larsson, 2014).

There are also sector differences in the overall degree of cooperation to influence EU policies, the main ones being that all sector unions cooperate to a lower overall degree than national, peak-level federations. This is as expected given that the national federations are members of the ETUC and tend to have more resources for international work. Below that, it seems that trade unions organizing professionals and the services sectors (including transportation and construction) cooperate to a lower degree to influence EU policies than unions in manufacturing and cross-sectoral unions. These results are also intelligible given that many of the manufacturing sectors are strong and have been under more competitive pressure and developed their European cooperation earlier and stronger than more nationally bound and sheltered service industries, which have been more of latecomers in European trade union cooperation (Bechter et al., 2011; cf. Bieler \& Lindberg, 2011, p. 223; Glassner \& Pochet, 2011, p. 13). Even if this explains the overall tendency, there is of course still a lot of unexplained internal sector variance that is not accounted for with this sector classification, and the results must be interpreted with this in mind.

The main focus of the analysis, however, has been differences between industrial relations regimes with regard to EU policy influencing cooperation. The highest degree of overall cooperation is found among the continental trade unions in the social partnership regime, while southern trade unions in the polarized/state-centered regime also show high degrees of cooperation. This is not surprising, since trade unions in these regimes have generally been more positive to the European project in general, and to transnational trade union cooperation in Europe (Hyman, 2005).

The fact that the Nordic trade unions in the organized corporatism regime and unions from the UK and other countries in the liberal pluralism regime tend to cooperate to a lower degree can be understood in the context of traditionally being more skeptical toward the EU project. In addition, even if they have been strongly involved in European trade union cooperation and organization, the Nordic unions, and particularly the Swedish, have often taken a cautious stance in pursuing joint action and in developing cooperative structures in an attempt to defend their own system of industrial relations (Bengtsson, 2015; Bieler \& Lindberg, 2011: 222; Busemeyer et al., 2008; Furåker \& Bengtsson, 2013; Furåker \& Lovén Seldén, 2013; Larsson, 2014; cf. Glassner \& 
Vandaele, 2012; Gumbrell-McCormick \& Hyman, 2013, p. 172ff.). Furthermore, the Nordic countries include unions from the non-EU member countries Iceland and Norway, and as shown, they have lower degrees of cooperation to influence EU policies.

In line with this overall argument, it is not surprising that the Central and Eastern European trade unions in the fragmented/state-centered regime have the lowest overall degree of cooperation. Not only are they latecomers to the EU context, but they are also comparatively weak on the national arena and have fewer organizational resources than unions in other regimes (Bieler \& Schulten, 2008; Hassel, 2009, p. 19; Léonard et al., 2012).

When using the social partnership regime as a benchmark for comparison - on the basis of their relatively high degree of cooperation through all seven channels several differences in the choice of EU policy influencing routes were found. Nordic trade unions are balanced toward the national route through strong cooperation with national political parties and authorities. They also put weight on their own trade union offices in Brussels. This strategy is in strong contrast to the southern unions that are mostly balanced toward the Brussels route, with their strong cooperation through the transnational trade union collaboration in the ETUFs and ETUC. The basis for this difference seems quite obvious, as the Nordic trade unions have a long history of corporatist cooperation at the national level based on their relatively strong position in relation to the state and employer organizations. They have also shown some skepticism toward the European level of trade union cooperation. They were the first to establish their own trade union offices in Brussels, and it has been claimed that they prefer to export their own traditions and strategies rather than learn from others (e.g., Bieler \& Lindberg, 2009; Busemeyer et al., 2008; Furåker \& Bengtsson, 2013). In contrast, the southern trade unions have generally been more enthusiastic about the European project. They have generally weaker relations to national level policies, and fewer channels of national influence, and therefore have higher hopes for European trade union organizations to influence EU policies (Greenwood, 2007, p. 10; cf. Glassner \& Vandaele, 2012).

In addition, one may note some particularities of the two regimes with the lowest degrees of overall cooperation. Trade unions in the liberal pluralism regime pursue a relatively high degree of cooperation through a specific Brussels route - as compared with all other regimes except the social partnership - with members or political groups in the EP. The emphasis may be related to the increasing focus on a 'logic of influence' and EU institutions by trade unions in this regime, at least in the UK (Bieler, 2005; Mitchell, 2007). Trade unions in the fragmented/state-centered regime in Central and Eastern Europe pursue relatively high cooperation though the ETUC. A reason for this might be that, for them just as for the southern unions, the ETUC may be seen as a channel through which they can strengthen their position at the national level. This is set against the fact that in these countries, there generally only exists what Hassel (2009, p. 19) speaks of as an 'illusory' form of national corporatism, which does not really give much influence for trade unions on policies (cf. Greenwood, 2007, p. 103). With regard to all other channels, trade unions in the liberal pluralism and fragmented/state-centered regimes report low degrees of cooperation in comparison to the other three regimes, particularly for cross-national regional trade union networks.

Even if there are some weaknesses in the data set, as discussed above, these results seem quite intelligible and they also confirm some tendencies pointed at in previous 
research. Since most research on this issue is of a qualitative case study kind, or have been oriented toward only a few of these channels, the more general picture given in this article contributes to our knowledge about to what extent differences in industrial relations regimes in Europe still play in trade union strategies. The results also confirm that sector differences and resources are important, and it seems that all of these factors have independent effects and are complementary from an explanatory perspective (cf. Bechter et al., 2011). In addition to the divergences in position in specific issues, these divergences in strategy are also part of the challenges that trade unions in Europe face in trying to influence EU policies.

However, one should not exaggerate the differences in trade union strategies and degrees of European cooperation, since these differences are smaller than the similarities, and since the data are less representative for some industrial relations regimes. Moreover, behind these differences, there might also be a tendency toward convergence. It is an open question whether the development goes in the direction suggested by Nergaard and Dølvik (2005, p. 56) in that the emphasis on the national route is decreasing to the benefit of the Brussels route. In fact, there may also be reasons for an increased trade union focus on the national EU policy influencing route during the last decade and for the future. Among the reasons one finds, as discussed above, is the pushing back of possibilities for trade union influence at the national level through the OMC and the voluntary national implementation of social dialogue agreements. There may also be tendencies toward a renationalization of trade union interests because of the economic crisis in Europe.

\section{References}

Bechter, B. and Brandl, B. (2014) Developments in European industrial relations, in Industrial Relations in Europe 2014. Brussels: European Commission, pp. 17-40.

Bechter, B., Brandl, B., and Meardi, G. (2011) From National to Sectoral Industrial Relations. Dublin: European Foundation for the Improvement of Living and Working Conditions.

Bengtsson, E. (2015/forthcoming) 'Swedish unions and the ETUC', in P. Tilly (ed) ETUC and the Development of European Trade Union Cooperation, Brussels: ETUI.

Bieler, A. (2005) 'European integration and the transnational restructuring of social relations: the emergence of labour as a regional actor', Journal of Common Market Studies 43(3): 461-484.

Bieler, A. and Goudriaan, J. W. (2011) 'Trade union and social movement cooperation in the defence of the European public sector', in A. Bieler, and I. Lindberg (eds), Global Restructuring, Labour and the Challenges for Transnational Solidarity. London: Routledge, pp. 177-190.

Bieler, A. and Lindberg, I. (2009) 'Swedish unions and globalization: labour strategies in a changing global order'. In: A. Bieler, I. Lindberg and D. Pillay (eds), Labour and the Challenges of Globalization - What Prospects for Transnational Solidarity? London: Pluto Press, pp. 199-216.

Bieler, A. and Lindberg, I. (2011) 'Conclusions. A variable landscape of emerging transnational solidarities', in A. Bieler, and I. Lindberg (eds), Global Restructuring, Labour and the Challenges for Transnational Solidarity. London: Routledge, pp. 220-231.

Bieler, A. and Schulten, T. (2008) 'European integration: a strategic level for trade union resistance to neoliberal restructuring and for the promotion of political alternatives?'. In. A. Bieler, I. Lindberg and D. Pillay (eds), Labour and the Challenges of Globalization - What Prospects for Transnational Solidarity? London: Pluto Press, pp. 231-247. 
Bernaciak, M. (2011) 'East-West European labour transnationalism(s). Rivalry or joint mobilization?' in A. Bieler, and I. Lindberg (eds), Global Restructuring, Labour and the Challenges for Transnational Solidarity. London: Routledge, pp. 33-47.

Bücker, A. \& Warneck, W. (eds) (2010) Viking - Laval - Rüffert: Consequences and Policy Perspectives. Brussels: ETUI.

Busemeyer, M. R., Kellerman, C., Petring, A. and Stuchlik, A. (2008) 'Overstreching solidarity? Trade unions' national perspectives on the European economic and social model', Transfer 14(3): 435-452.

Clauwaert, S. (2011) '2011: 20 years of European interprofessional social dialogue: achivements and prospects', Transfer 17(2): 169-179.

Crouch, C. (1999) Social Change in Western Europe. Oxford: Oxford University Press.

de Boer, R., Benedictus, H. and van der Meer, M. (2005) 'Broadening without intensification: The added value of the European social and sectoral dialogue', European Journal of Industrial Relations 11(1): 51-70.

Dølvik, J. E. (1997) Redrawing Boundaries of Solidarity? ETUC, Social Dialogue and the Europeanisation of Trade Unions in the 1990s. Report No 238. Oslo: Fafo.

Dølvik, J. E. and Ødegård A. M. (2012) 'The struggle over the services directive: the role of the European Parliament and the ETUC', Labor History 15(1): 69-89.

Erne, R. (2008) European Unions. Labor's Quest for a Transnational Democracy. Ithaca: Cornell University Press.

European Commission (2010) European Sectoral Dialogue. Recent Developments. Luxembourg: Publication Office.

Furåker, B. and Bengtsson, M. (2013) 'On the road to transnational cooperation? Results from a survey among European trade unions', European Journal of Industrial Relations 19(2): 161-177.

Furåker, B. and Lovén Seldén, K. (2013) 'Trade union cooperation on statutory minimum wages. A study of European trade union positions', Transfer 19(4): 507-520.

Gajewska, K. (2008) 'The emergence of a European labour protest movement?', European Journal of Industrial Relations 14(1): 104-121.

Glassner, V. (2013) Central and Eastern European industrial relations in the crisis: national divergence and path-dependent change, Transfer 19(2): 155-169.

Glassner, V. and Pochet, P. (2011) Why Trade Unions Seek to Coordinate Wages and Collective Bargaining in the Eurozone. Brussels: ETUI.

Glassner, V. and Vandaele, K. (2012) 'Which way towards Europeanization of trade union strategies? Regional differences in trade union officers' views'. Paper presented at ILERA World Congress 2012: Philadephia.

Gold, M., Cressey, P. and Léonard, E. (2007) 'Whatever happened to social dialogue? From partnership to managerialism in the EU employment agenda', European Journal of Industrial Relations 13(1): 7-25.

Greenwood, J. (2007) Interest Representation in the European Union (2 ed.). Basingstoke: Palgrave Macmillan.

Gumbrell-McCormick, R. and Hyman, R. (2013) Trade Unions in Western Europe. Hard Times, Hard Choices. Oxford: Oxford University Press.

Hassel, A. (2009) 'Policies and politics in Social Pacts in Europe', European Journal of Industrial Relations 15(7): 7-26.

Hyman, R. (1994) 'Industrial Relations in Western Europe: An era of ambiguity?' Industrial Relations 33(1): 1-24.

Hyman, R. (2005) 'Trade unions and the politics of the European social model', Economic and Industrial Democracy 26(9): 9-40.

Kaeding, M. and Obholzer, L. (2012) 'The EU and formalisation of sectoral social dialogue: lessons from the sector of central public administration', in S. Smismans (ed), 
The European Union and Industrial Relations. Manchester: Manchester University Press, pp. 40-55.

Keller, B. and Weber, S. (2011) 'Sectoral social dialogue at the EU level: problems and prospects of implementation', European Journal of Industrial Relations 17(3): 227-243.

Larsson, B. (2012) 'Obstacles to transnational trade union cooperation in Europe - results from a European survey', Industrial Relations Journal, 43(2): 152-170.

Larsson, B. (2014) 'Transnational trade union action in Europe - the significance of national and sectoral industrial relations', European Societies, 16(3): 378-400.

Léonard, E., Perin, E. and Pochet, P. (2011) 'The European sectoral social dialogue: questions of representation and membership', Industrial Relations Journal 42(3): 254-272.

Léonard, E., Perin, E. and Pochet, P. (2012) 'The European sectoral social dialogue as a tool for coordination across Europe?', in S. Smismans (ed), The European Union and Industrial Relations. Manchester: Manchester University Press, pp. 56-77.

Marginson, P. (2014) 'Coordinated bargaining in Europe: From incremental corrosion to frontal assault?', European Journal of Industrial Relations, Published online ahead of print (DOI: 10.1177/0959680114530241).

Meardi, G. (2012) 'Industrial relations after European state traditions?'. In L. Burroni, M. Keune and G. Meardi (eds), Economy and Society in Europe. A Relationship in Crisis. Cheltenham: Edward Elgar, pp. 100-123.

Mitchell, K. (2007) 'Trade unions and EU politics: explaining variation in European strategies'. Paper presented at the EUSA Conference: Montreal.

Müllensiefen, T. (2012) 'The European cross-sectoral social dialogue between autonomous action and regulatory involvement', in S. Smismans (ed), The European Union and Industrial Relations. Manchester: Manchester University Press, pp. 25-39.

Müller, T., Platzer, H.-W. and Rüb, S. (2010) 'Transnational company policy and coordination of collective bargaining - new challenges and roles for European Industry Federations', Transfer 16(4): 509-524.

Nergaard, K. and Dølvik, J.E. (2005) Internasjonalisering og fagorganisering. En undersøkelse av de nordiske fagforbundenes internasjonale arbeid. [Internationalization and Trade Union Organization. A Study of the Nordic Trade Unions' International Work] Stockholm: National Institute for Working Life.

Princen, S. and Kerremans, B. (2012) 'Opportunity structures in the EU multi-level system', West European Politics 31(6): 1129-1146.

Pulignano, V. (2009) 'International cooperation, transnational restructuring and virtual networking in Europe', European Journal of Industrial Relations 15(2): 187-205.

Scheuer, S. (2011) 'Union membership variation in Europe: A ten-country comparative analysis', European Journal of Industrial Relations 17(1): 57-73.

Schroeder, W. and Weinert, R. (2004) 'Designing institutions in European industrial relations: a strong Commission versus weak trade unions?', European Journal of Industrial Relations 10(2): 199-217.

Smismans, S. (2012) 'The European Union: institution-builder, arena and policy context for industrial relations', in S. Smismans (ed), The European Union and Industrial Relations. Manchester: Manchester University Press, pp. 1-21.

Svensson, S. and Jacobsson, G. (2009) Brännpunkt Bryssel. Tjugo àr av facklig bevakning $i$ EU. [Focal Point Brussels. Twenty Years of Trade Union Coverage in the EU] Stockholm: Bilda förlag.

Traxler, F., Brandl, B., Glassner, V. and Ludvig, A. (2008) 'Can cross-border bargaining coordination work? Analytical reflections and evidence from the metal industry in Germany and Austria', European Journal of Industrial Relations 14(2): 217-237. 
Waddington, J. (2005) 'Trade unions and the defence of the European Social Model', Industrial Relations Journal 36(6): 518-540.

Welz, C. (2008) The European Social Dialogue under Articles 138 and 139 of the EC Treaty: Actors, Processes, Outcomes. Alphen aan den Rijn: Kluwer.

Visser J., Beentjes M., van Gerven M. and Di Stasio V. (2009) 'The quality of industrial relations and the Lisbon Strategy'. In Industrial Relations in Europe 2008. Brussels: European Commission, pp. 45-72.

Vos, K. (2007) 'European convergence and the EU social model'. In Leisink, P., Steijn, B. and Veersma, U. (eds), Industrial Relations in the New Europe. Enlargement, Integration and Reform. Cheltenham: Edward Elgar, pp. 23-39.

\section{End notes}

1 The ETUFs were previously called EIFs (European Industry Federations).

2 Before choosing to do this, I performed a PCA analysis on the items. Since it produced just one factor with eigenvalue $>1$, and the Cronbach's alpha of the whole scale is above 0.8 and decreasing if items are deleted, I found it reasonable to create a summated index. 